УДК 811.111:37.091.32:004

Ірина Карпа, кандидат філологічних наук, доцент кафедри порівняльної педагогіки та методики викладання іноземних мов Дрогобицького державного педагогічного університету імені Івана Франка

\title{
ПЛАНУВАННЯ УРОКІВ АНГЛІЙСЬКОЇ МОВИ З ВИКОРИСТАННЯМ ІНТЕРНЕТ-ТЕХНОЛОГІЙ
}

У статті розглядається проблема планування уроків англійської мови з використанням Інтернеттехнологій для учнів з високим і низьким рівнями володіння мовою. Авторка досліджує фрагменти уроків різних рівнів, які поділяються на три частини: розминку, основну частину $і$ перспективи, надає взіриі запитань, окреслює види діяльності, які можна віднести до перспектив подальшої роботи. Для вищого рівня володіння мовою запропоновано план уроку на тему “Кінозірки”, який передбачає відповіді на запитання, реагування на інформацію, формування інтересу, дослідження техніки інтерв'ю, способи реагування на соціальному рівні. Для нижчого рівня володіння мовою взірием виступає план уроку “Запозичені слова”, у якому учні мають можливість вдосконалити словниковий запас по темі “Краӥни $і$ мови”.

Ключові слова: розминка, основна частина, перспективи, веб-сайт, Інтернет-мережа, учень, викладач, урок.

Табл. 2. Лім. 8.

Iryna Karpa, Ph.D.(Philology), Associate Professor of the Comparative Education and Foreign Languages Teaching Methodology Department Drohobych Ivan Franko State Pedagogical University

\section{PLANNING ENGLISH LANGUAGE LESSONS USING THE INTERNET-TECHNOLOGIES}

The article discusses the problem of planning of English language lessons using the Internet-technologies for the pupils with high and low levels of mastering og English. first of all, thing a teacher should plan a lesson well, visit the websites and make sure that they are reliable. The next step is to consider the differences between the plan of technology-based lesson and the lesson plans you usually produce.

A typical web-based lesson is divided into three parts: warm up, the main web part, and procedure. The warm up part of the lesson is based on introductory activities, the interest-generating ideas, and so on. This part prepares the learners for what they are going to be doing in the web part of the lesson. In the web section of the lesson, it's important to spend as much time as you need working with the computers. If you have limited access to computers, or perhaps only one computer in the classroom, you can print off the web-based materials you want to use with your learners in advance, and simply use the print version.

The teacher should remember that the learners have their favourite websites, and it is well worth investigating whether these can be incorporated into your classroom teaching, partly as a motivator, but also as a link to their lives, interests and experiences outside the class. This will help them to understand the value of the technology applied in class. The learners should have a clearly-defined task to achieve and a clearly-defined time frame for achievment. Once the group has got what you intended from the computers, it's time to move them back to the classroom for the procedure stage of the lesson. This part should deal with the tasks set for the web part and then proceed with more familiar follow-up activities to summarise the lesson.

"Movie stars" is a sample lesson plan based on this structure. The contemporary nature of most website content makes the web an ideal source of material. This is for an upper-intermediate or advanced leaners, concentrating on famous movie stars and their lives and work. The language covered areas are: asking and answering questions, reacting to information, and showing interest. The learners will also explore the interview techniques, and ways of interacting on a social level.

Keywords: warmer, web part, what next, web-site, Internet, a pupil, a teacher, a lesson.

П остановка проблеми. Інформатизація та комп'ютеризація освіти у сучасному глобалізованому світі передбачає як підготовку вчителя до використання інноваційних технологій, так і готовність учня працювати самостійно, особливо у процесі вивчення англійської мови. Закони України "Про освіту", "Про вищу освіту”, “Про мови”, Державна програма “Вчитель”, Державна національна програма "Освіта" (Україна XXI століття), Концепція педагогічної освіти, Концепція мовної освіти в Україні, Національна доктрина розвитку освіти в Україні, Національна стратегія розвитку освіти в Україні на період до 2021 року, Європейський мовний портфель та Загальноєвропейські Рекомендації з мовної освіти 
окреслюють головні напрями втілення цієї тенденції в життя.

Аналіз останніх досліджень і публікацій. Дослідженням проблеми застосування можливостей сучасних засобів інформаційних та телекомунікаційних технологій у навчальному процесі займаються вітчизняні та зарубіжні науковці починаючи з 90-х років XX століття. У контексті даної статті слід виділити наукові праці присвячені методиці навчання англійської мови за допомогою сучасних технологій $[2 ; 4 ; 8]$, Інтернет-ресурсам, які застосовують студенти при вивченні англійської мови $[1 ; 3 ; 6]$, дослідження освітніх можливостей ресурсів Британської Ради [5], особливостей використання мультимедійних технологій у процесі навчання іноземної мови [7]. Проте, досі не досліджено особливості планування уроків англійської мови 3 використанням Інтернет-технологій.

Мета статті. Розглянути проблему планування уроків англійської мови 3 використанням Інтернет-технологій для учнів 3 високим i низьким рівнями володіння мовою.

Виклад основного матеріалу. Викладач повинен оцінити і вирішити, які веб-сайти можна використовувати як частину навчального матеріалу. Наступним кроком буде порівняти новий план уроку зі стандартними конспектами, які викладач зазвичай готує. Потрібно відповісти на питання чим конспект на основі Інтернеттехнологій відрізняється від звичайного, які можуть бути труднощі і як 3 ними справитись.

Перш за все потрібно відвідати веб-сайти, які викладач планує подавати на уроці та впевнитися, що вони надійні, тобто створені авторитетними організаціями, оскільки багато персональних веб-сторінок мають тенденцію подавати неправдиву інформацію.

Для того, щоб зберегти сторінку і бути впевненим, що зміст опрацьовано можна використовувати Закладки. Плануючи урок 3 використанням Інтернет-технологій, його умовно можна поділити на три частини: розминку, основну частину, перспективи $[8,35]$.

Розминка вводиться як вступна діяльність, яка викликає зацікавлення. Ця частина готує учнів до того, чим вони будуть займатися в головній частині. У головній частині учням слід провести достатньо часу за комп'ютером. Отже, перехід від традиційної класної кімнати у комп'ютерну має ряд переваг при детальному плануванні. Якщо у викладача обмежений доступ до комп'ютера чи наявний тільки один ноутбук у класі, можна видрукувати онлайн матеріали.

Учні можуть запропонувати свої веб-сайти, які також варті уваги для того, щоб їх залучити у навчальний процес в першу чергу як мотиватор, а також як зв'язок з їхнім життям, інтересами та досвідом за межами класної кімнати. Це допоможе їм побачити цінність нових технологій застосованих на уроці.

Слід пам'ятати, що учні повинні мати чітко окреслене завдання та визначений ліміт часу при роботі з онлайн-матеріалами. Наприклад, можна розглянути тему "Movie Stars" на основі онлайн матеріалів ресурсу The Film Programme на сайті BBCRadio4. Учні матимуть змогу ознайомитись 3 інтерв'ю реальних акторів у реальній програмі, що $є$ важливим мотиваційним елементом. Сучасний матеріал більшості веб-сайтів робить Інтернет-мережу цінним джерелом допоміжних ресурсів для вчителя $[8,36]$.

Такий тип уроку можна використовувати на рівнях upper-intermediate та advanced, звертаючи увагу на біографії відомих зірок та їхніх роботах. До завдань на даному уроці можна включити відповіді на запитання, реагування на інформацію, формування інтересу, дослідження техніки інтерв'ю, способи реагування на соціальному рівні.

Як розминку можна використати розмову про улюбленого актора/ актрису кожного учня та їхні найкращі ролі. Потім дискусію можна розвинути спілкуючись на різноманітні дотичні теми: улюблені фільми, останні відвідини кінотеатру, фільми, які з'являться незабаром, найкращі і найгірші фільми тощо.

Наприклад, це може бути у формі діалогу (Talk to your partner)

- What kind of films do you like?

- Who are your favourite actors?

- What's the best film you've ever seen?

- What's the worst film you've ever seen?

- When did you last go to the cinema?

- Which movie star would you like to interview?

- What would you ask that person?

Після розминки учні працюють з сайтом ВВС та обирають актора, інтерв'ю якого вони б хотіли прослухати. Слухання не передбачає перегляд аудіотранскрипції чи субтитрів. Учні отримують завдання занотувати головні тези інтерв'ю, а також його структуру - як розмова розпочиналась і розвивалась. Наприклад:

Listen to your chosen interview

- Who was interviewed? Who was the interviewer?

- What topics were discussed?

- How did the interviewer construct the interview?

- Introduction

- Initial questions

- Reactions to answers 
- Follow-up questions and comments

- Conclusions

- How did the interviewee react?

- Getting started

- Answers to questions

- Additional information

- Conclusions

- Make a note of some of the useful interview expressions.

Після опрацювання веб-сайту можна обговорити основні теми інтерв'ю, що учні дізналися та що очікували, але не почули. Учні виписують нові фрази та слова, які вони почули, а вчитель записує їх на дошці, аналізуючи структуру, мету тощо.

До перспектив подальшої роботи можна віднести наступні види діяльності: - Speaking activity: an interview.

Учні працюють у парах (наприклад відома людина і ведучий програми) та складають діалогінтерв'ю. Цей діалог можна записати в аудіо або відео форматі для подальшого мовленнєвого опрацювання.

- Writing activity: a day in the life.

Таку інформацію можна часто побачити у недільній пресі Великобританії, де відому людину розпитують про типовий день її життя або особливо цікавий день тижня, що пройшов.

- Writing activity: an interview.

Цей вид діяльності можна виконувати як

низьким рівнем володіння мовою є недостатнє розуміння ними наданих для опрацювання текстів. Учні з низьким володінням мовою вважають, що вони повинні зрозуміти весь об'єм тексту, тому викладач заздалегідь повинен попередити їх і переконати, що стовідсоткове розуміння не $\epsilon$ необхідністю. Вибір відповідних веб-сайтів підвищить рівень психологічного комфорту учнів. Отже, для оптимального розуміння учнями вебсайту він повинен містити:

- простий текст з якісною презентацією;

- нелінгвістичну базу даних, яку легко інтерпретувати (наприклад, дані у формі чарту, такі як сторінка прогнозу погоди тощо);

- візуальні матеріали, у такому випадку завдання буде базуватися на основі даних матеріалів;

- контент, характерний для спеціалізованих сайтів для вивчення англійської мови, призначений для певної цільової аудиторії.

Наприклад, можна запропонувати урок "Borrowed Words" для низького рівня володіння англійською мовою. Вокабуляр цього уроку бути містити країни і мови. Розминкою на даному уроці буде слугувати запитання чи знають учні слова рідної мови, які $є$ запозиченими з інших мов. Потім викладач малює на дошці таблицю і допомагає учням 3 англомовними версіями запозичених слів. Таблиця 1 матиме наступний вигляд.

Таблиця 1.

Англомовні версії запозичених слів

\begin{tabular}{|l|l|l|l|l|l|l|}
\hline $\begin{array}{l}\text { Original } \\
\text { Country }\end{array}$ & $\begin{array}{l}\text { Original } \\
\text { Language }\end{array}$ & $\begin{array}{l}\text { Original } \\
\text { word }\end{array}$ & $\begin{array}{l}\text { Your } \\
\text { country }\end{array}$ & $\begin{array}{l}\text { Your } \\
\text { language }\end{array}$ & $\begin{array}{l}\text { Word in } \\
\text { your } \\
\text { language }\end{array}$ & $\begin{array}{l}\text { English } \\
\text { Version }\end{array}$ \\
\hline Spain & Spanish & Paella & Sweden & Swedish & Paella & Paella \\
\hline
\end{tabular}

індивідуально, так і в парах, наприклад один учень може писати питання, а інший відповіді. Цей вид можна презентувати як інтерв'ю за допомогою електронної пошти.

- Writing activity: a biography.

Цей вид діяльності передбачає роботу 3 Інтернет-мережею для більш детального збору інформації про відомих осіб $[8,38]$.

Якщо рівень англійської мови учнів високий, можна обговорити різницю у мовленні, тактиках журналіста у різних типах інтерв'ю: соціальному i формальному.

Можна також розглянути роботу з Інтернетмережею для учнів 3 низьким володінням англійською мовою. У такому випадку вибір вебсайтів буде більш обмеженим, ніж для учнів вищого рівня. Типовою проблемою учнів 3
В основній частині учні працюють у парах $\mathrm{i}$ кожному учневі видається копія напарника. Учні мають час, щоб заповнити свою колонку, залишаючи наступну порожньою для іншої фази діяльності. Потрібно зазначити, що учні повинні не тільки ідентифікувати мову і країну для поданих слів, але й також знайти слова, які підходять до даної мови чи країни. Наприклад:

У наступній фазі учні повинні задати напарнику запитання для того, щоб заповнити іншу частину таблиці. Наприклад, можна задати такі запитання стосовно таблиці 2 :

- What language does the word sauna come from?

- What country does parachute come from?

- Can you tell me a Ukrainian word used in English?

Кожній парі дається час, щоб поставити 
Таблиця 2.

Borrowed Words in English Use the website to complete your part of the table

\begin{tabular}{|c|c|c|c|c|c|}
\hline \multicolumn{3}{|c|}{ Student A } & \multicolumn{3}{|c|}{ Student B } \\
\hline Word & Country & Language & Word & Country & Language \\
\hline Kidnap & & & sauna & & \\
\hline & & Greek & & Japan & \\
\hline Lottery & & & & & Russian \\
\hline & Italy & & parachute & & \\
\hline Paper & & & & Norway & \\
\hline
\end{tabular}

запитання, відповісти на них та заповнити таблицю. Учитель допомагає учням 3 кожною лексичною проблемою, яка може виникнути, використовуючи дошку $[8,41]$.

Перспективою цього уроку може бути вдосконалення вокабуляру по темі “Країни i мови”. Додатковим завданням для учнів може бути проектна робота: зібрати англійські слова, які зустрічаються в побутовому середовищі, наприклад, по телебаченню, на рекламних білбордах чи знаках. Таким чином учні можуть створити постери для класної кімнати.

Плануючи ретельно і адаптуючи структурний підхід до способів використання веб-сайтів на уроках важливо підбирати різні способи презентації матеріалу. Більшість часу потрібно застосовувати веб-сайти для того, щоб забезпечити учнів знаннями і змістом, до яких вони не мають доступу та які слугуватимуть додатковими для традиційних матеріалів. Ця діяльність може бути надзвичайно мотивуючою для них і привести до кращої продуктивності у навчанні.

Слід зазначити, що необов'язково включати веб-сайти з анімацією, аудіо- та відеоконтентом для того, щоб зацікавити учнів. Достатнім буде навіть простий текстовий матеріал, який може принести користь при опрацюванні і подальшому обговоренні. Проте, під час роботи з веб-сайтом можуть виникнути певні технічні проблеми, тому викладач повинен бути готовий запобігти цьому. Викладач повинен використовувати досвід інших вчителів та попередників, щоб справитися 3 технічною стороною уроку. Зараз проводяться різні майстер-класи як на обласному, так і на місцевому рівні з метою навчити викладачів старшого покоління користуватися сучасними інформаційно-комунікаційними технологіями, оскільки у цьому аспекті молодь є більш прогресивною і навіть деякі учні можуть допомогти викладачу усунути технічні проблеми, які виникають на уроці. Викладачу також слід навчитися зберігати веб-сторінки чи YouTube подкасти на свій ноутбук чи комп'ютер.
Викладач може також організовувати електронне листування учнів зі своїми англомовними ровесниками з різних країн. Якщо дозволяє швидкість Інтернету, можна організувати Skype-дискусії. Для цього краще, щоб учні працювали парами за одним комп'ютером, можна навіть групуватися втрьох, це буде заохочувати учнів до усного спілкування і подолає “комп'ютерний бар'єр”, який є характерним для уроків, які базуються на Інтернет-технологіях.

Викладач також повинен так організувати розміщення комп'ютерних столів, щоб бачити монітори та мати вільний доступ до учнів.

Висновки. Не кожен веб-сайт, який обирає викладач, зможе зацікавити учнів, для цього потрібно попередньо узгодити з учнями їхнє коло інтересів. Учні повинні зрозуміти, що використання сучасних автентичних Інтернетматеріалів може бути корисним для них, слід обговорити їхнє ставлення до Інтернет-технологій в загальному розумінні цього слова, переконати ïx, що вони можуть виступати не тільки засобом для комп'ютерних ігор, але й потужним навчальним засобом, додатковим до книг та підручників. Загалом використання веб-сайтів $є$ найлегшим і найменш проблематичним способом впровадження Інтернет-технологій на уроці.

\section{ЛІТЕРАТУРА}

1. Боднар С.В. Використання Інтернеттехнологій у системі автономного вивчення професійно-орієнтованої іноземної мови студентами немовних спеціальностей / C.B. Боднар // Інформаційні технології $i$ засоби навчання. - 2013. - Том 34. - №2. - С. 75-81.

2. Интернет в гуманитарном образовании: учеб. пособие для студентов высш. учеб. заведений / Под ред. Е.С. Полат. - М.: Владос, 2001. $-272 c$.

3. Костенко І.Г. Використання Інтернет-ресурсів науроках англійськоїмови/І.Г.Костенко//Таврійський вісник освіти. - 2013. - №1 (41). - C. 170-176. 
4. Новые педагогические и информачионные технологии в системе образования / Е.С. Полат, М.Ю. Бухаркина, М.В. Моисеева, А.Е. Петров; Под. ред. Е.С. Полат. - М.: Издательский ичентр “Академия”, 2002.-272 c.

5. Романишин I. Використання Інтернет ресурсів Британської Ради метою контролю та самоконтролю у навчанні англійської мови / I. Романишин. [Електронний ресурс]. - Режим docmyny: http://194.44.152.155/elib/local/676.pdf

6. Титова С.В. Виды электронной сети и их дидактические возможности / С.В. Титова // Вестник Московского университета. - Серия 19. Лингвистика и межкультурная коммуникация. 2010. - №3. - C. 37-51.

7. Токменко О. Інформаційні технології у викладанні іноземних мов: сьогодні і скрізь віки на допомогу / О. Токменко // Іноземні мови в навчальних закладах. - 2006. - № 2. - C. 98-100.

8. Dudeney G., Hockly N. How to teach English with technology / Series editor: Jeremy Harmer. Harlow: Pearson Education Limited, 2007. - 192 p.

\section{REFERENCES}

1. Bodnar, S.V. (2013). Vykoristannya Internettehnologiy u systemi avtonomnogo vyvchennya profesiyno-orientovanoyi inozemnoyi movy studentamy nemovnyh spetsialnostey [The use of Internet-technologies in the system of autonomous learning of professionally-oriented foreign language by the students of nonphilological specialties]. Informational Technologies and Means of Teaching. No 34(2), pp. 75-81. [in Ukrainian].

2. Polat, E.S. (Ed.). (2001). Internet $v$ gumanitarnom obrazovanii: uchebnoye posobie dlya studentov vysshy uchebnyh zavedeniy [Internet in humanities: educational accessory for the students of higher educational establishments]. Moskva: Vlados, 272 p. [in Russian].

3. Kostenko, I.G. (2013).Vykoristannya Internetresursiv na urokah angliyskoyi movy [The use of Internet-resources at the English language lessons]. Educational Bulletin of Tavriya. No 41, pp. 170-176. [in Ukrainian].

4. Polat, E.S., Buharkina, M.Yu., Moiseeva, M.V. \& Petrov, A.E. (2002). Novye pedagogicheskie $i$ informatsionnye tehnologii v sisteme obrazovaniya [New pedagogical and informational technologies in the system of education]. Editor Polat, E.S. Moskva: Akademiya, 272 p. [in Russian].

5. Romanishin, I. Vykoristannya Internet resursiv Brytanskoyi Rady z metoyu kontrolyu ta samokontrolyu u navchanni angliyskoyi movy [The use of Internet resources of the British Council for control and self-control in the English language teaching]. [Electronic resourse]. Available at: http:// 194.44.152.155/elib/local/676.pdf [in Ukrainian].

6. Titova, S.V. (2010). Vidy elektronnoy seti $i$ ih didakticheskie vozmozhnosti [Types of electronic network and their didactic opportunities]. Bulletin of the Moscow University. Series: linguistics and intercultural communication, no. 19 (3), pp. 37-51. [in Russian].

7. Tokmenko, O. (2006). Informatsiyni tehnologiyi $u$ vykladanni inozemnih mov: sogodni $i$ skriz viki na dopomogu [Informational technologies in foreign language teaching: today and through ages for help]. Foreign Languages in Educational Establishments. No. 2, pp. 98-100. [in Ukrainian].

8. Dudeney, G. \& Hockly, N. (2007). How to teach English with technology / Series editor: Jeremy Harmer. Harlow: Pearson Education Limited. 192 p. [in English].

Стаття надійшла до редакції 17.01.2018

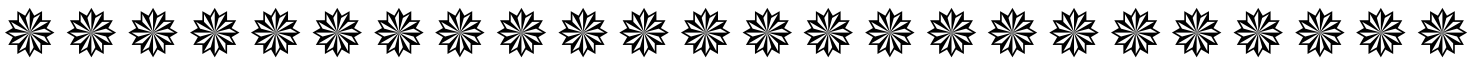

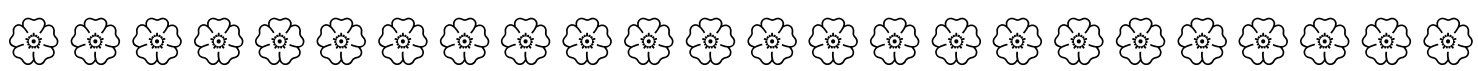 "Навчання без міркування - даремне, міркування без навчання - небезпечне".}

Конфучій

давньокитайський білособ

"Вчіться у вчора, живіть сьогодні, сподівайтеся на завтра. Толовне - не припиняти задавати питання ... Ніколи не втрачайте священної допитливості". Альберт Ейнштейн один із засновників сучасної теоретичної бізики, лауреат Нобелівської премії з бізики

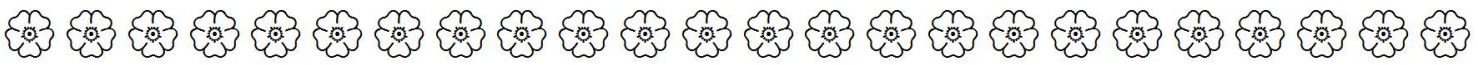

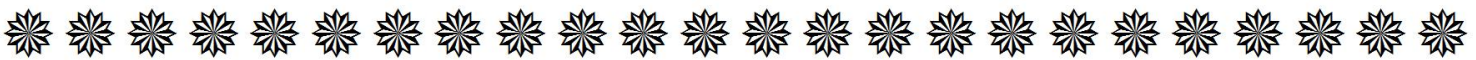

